\title{
Genetic analysis of efficiency traits in Austrian dairy cattle and their relationships with body condition score and lameness
}

\author{
A. Köck, ${ }^{*}$ M. Ledinek, $†$ L. Gruber,† F. Steininger, ${ }^{*}$ B. Fuerst-Waltl,† and C. Egger-Danner*1 \\ *ZuchtData EDV-Dienstleistungen $\mathrm{GmbH}$, Dresdner Str. 89/19, 1200 Vienna, Austria \\ †University of Natural Resources and Life Sciences, Department of Sustainable Agricultural Systems, Division of Livestock Sciences, \\ Gregor-Mendel-Str. 33, 1180 Vienna, Austria \\ ¥Agricultural Research and Education Centre, Raumberg 38, 8952 Irdning-Donnersbachtal, Austria
}

\section{ABSTRACT}

This study is part of a larger project whose overall objective was to evaluate the possibilities for genetic improvement of efficiency in Austrian dairy cattle. In 2014, a 1-yr data collection was carried out. Data from 6,519 cows kept on 161 farms were recorded. In addition to routinely recorded data (e.g., milk yield, fertility, disease data), data of novel traits [e.g., body weight $(\mathrm{BW})$, body condition score (BCS), lameness score, body measurements] and individual feeding information and feed quality were recorded on each test-day. The specific objective of this study was to estimate genetic parameters for efficiency (related) traits and to investigate their relationships with BCS and lameness in Austrian Fleckvieh, Brown Swiss, and Holstein cows. The following efficiency (related) traits were considered: energy-corrected milk (ECM), BW, dry matter intake (DMI), energy intake (INEL), ratio of milk output to metabolic $\mathrm{BW}\left(\mathrm{ECM} / \mathrm{BW}^{0.75}\right)$, ratio of milk output to DMI (ECM/DMI), and ratio of milk energy output to total energy intake (LE/INEL, LE = energy in milk). For Fleckvieh, the heritability estimates of the efficiency (related) traits ranged from 0.11 for LE/ INEL to 0.44 for BW. Heritabilities for BCS and lameness were 0.19 and 0.07 , respectively. Repeatabilities were high and ranged from 0.30 for LE/INEL to 0.83 for BW. Heritability estimates were generally lower for Brown Swiss and Holstein, but repeatabilities were in the same range as for Fleckvieh. In all 3 breeds, moreefficient cows were found to have a higher milk yield, lower BW, slightly higher DMI, and lower BCS. Higher efficiency was associated with slightly fewer lameness problems, most likely due to the lower BW (especially in Fleckvieh) and higher DMI of the more-efficient cows. Body weight and BCS were positively correlated. Therefore, when selecting for a lower BW, BCS is required as additional information because, otherwise, no

Received June 3, 2017.

Accepted September 6, 2017.

${ }^{1}$ Corresponding author: egger-danner@zuchtdata.at distinction between large animals with low BCS and smaller animals with normal BCS would be possible. Key words: efficiency, body condition score, lameness, genetic parameter

\section{INTRODUCTION}

The dairy industry is under constant pressure to further improve production efficiency and a greater emphasis is being placed on reducing the negative effects of dairy production on the environment. Emissions of greenhouse gas and nutrient losses to the environment should be reduced (Connor, 2015). Improving feed efficiency provides a way to tackle both challenges. The focus is on how much milk is produced from a feed unit and not the performance per animal (VandeHaar, 2014).

Feed efficiency is a complex trait, with many definitions in lactating dairy cows. Efficiency can be expressed as ratio-based traits (e.g., ratio of milk output to feed input) or residual-based traits (e.g., residual feed intake; Berry and Crowley, 2013). However, the difficulty of recording feed intake hinders direct selection for feed efficiency. As an alternative, the use of moderately to highly correlated indicator traits (e.g., milk yield, BW) has been suggested (Berry and Crowley, 2013).

The Federation of Austrian Cattle Breeders initiated the project "Efficient Cow" at the end of 2012 with a 1 -yr data collection in 2014. In addition to routinely recorded data (e.g., milk yield, fertility, disease data), data of novel traits (e.g., BW, BCS, lameness score, body measurements) and individual feeding information and feed quality were recorded at each test-day. Data were recorded in the Austrian central cattle database following extensive plausibility checks. The overall goal of this project was to develop and evaluate efficiency traits in dairy cattle breeding considering Austrian circumstances. Farms were selected to cover diverse production environments in Austria, ranging from mountainous regions to intensive farms in climatically favorable regions. Despite this, the average herd 
size (32.6 cows) was approximately twice as high as the Austrian average (Steininger et al., 2015).

Detailed phenotypic analysis results of the "Efficient Cow" data are given by Gruber and Ledinek (2017) and Ledinek et al. (2017). The objectives of this study were to estimate genetic parameters for ECM, BW, DMI, energy intake, and efficiency traits, and to investigate their relationships with BCS and lameness based on data from the "Efficient Cow" project.

\section{MATERIALS AND METHODS}

\section{Data}

Data of routinely recorded milk yield, as well as data of novel traits (BW, BCS, and lameness) and individual feeding information and feed quality recorded by trained staff from the milk recording organizations on each test-day (approximately every $5 \mathrm{wk}$ ), was available from the "Efficient Cow" project from January 2014 to December 2014. Further information about recording diet information, handling of forage analyses, nutrient content of concentrate, and calculation of energy content of forage is given in Ledinek et al. (2016, 2017). In total 45,944 records from 6,519 cows from 161 herds were available.

\section{Traits}

$\boldsymbol{E} \boldsymbol{C M}$. Milk yield was standardized to ECM at each test-day according to the recommendations of GfE (2001) as follows:

$$
\mathrm{ECM}=(0.38 \times \text { fat percentage }+0.21
$$

$\times$ protein percentage +0.95$) / 3.2 \times$ milk yield

$\boldsymbol{B} \boldsymbol{W}$. In Austria, standard housing systems for dairy cows lack equipment for routine weighing. During the observation period of the project, all cows were weighed on each test-day. If no scale was available on-farm, a mobile device was used.

DMI. As individual feed intake was impossible to measure on-farm, DMI at each test-day had to be estimated. For this purpose, the prediction model no. 1 of Gruber et al. (2004) was used:

$$
\begin{gathered}
\text { DMI }=3.878+\text { Country } \times \text { Breed }+ \text { Parity } \\
+ \text { DIM }+ \text { bBW } \times \text { BW }+ \text { bMilk yield } \times \text { Milk yield } \\
+ \text { bConcentrate amount } \times \text { Concentrate amount } \\
+0.858 \times \mathrm{NE}_{\mathrm{L}} \text { Forage } .
\end{gathered}
$$

The model considers the fixed effects of country and breed, parity, DIM, and the regression coefficient for the energy content of forage $\left(\mathrm{NE}_{\mathrm{L}}\right.$ Forage). Depending on the DIM, the regression coefficients (b) for BW, milk yield, and amount of concentrate have to be calculated. Feeding information was recorded for each cow on each test-day. Dairy cow rations and forage analyses were recorded and included in the prediction as well. A more detailed description of the model and calculation is given by Ledinek et al. (2016). Jensen et al. (2015) evaluated the up-to-date feed intake models of NRC (2001), Volden et al. (2011), TDMI-Index (Huhtanen et al., 2011), Wageningen-DCM (Zom et al., 2012a,b), and Gruber model no. 5 (Gruber et al., 2004) and found the Gruber model to be the most accurate. In this study, Gruber model no. 1 was chosen to take advantage of the high coefficient of determination $\left(\mathrm{R}^{2}=86.7 \%\right)$ and the low residual standard deviation $(\mathrm{RSD}=1.32 \mathrm{~kg}$ of $\mathrm{DM})$ compared with prediction model no. $5\left(\mathrm{R}^{2}=\right.$ $83.5 \%, \mathrm{RSD}=1.46 \mathrm{~kg}$ of DM; Gruber et al., 2004).

Energy Intake. For each cow and test-day, energy intake (INEL) was calculated as follows, whereas DMI was estimated according to the model of Gruber et al. (2004):

$$
\mathrm{INEL}=\mathrm{DMI} \times \text { energy concentration }
$$

$$
\text { (MJ of } \mathrm{NE}_{\mathrm{L}} / \mathrm{kg} \text { of } \mathrm{DM} \text { ). }
$$

Efficiency Traits. Calculation of efficiency parameters was based on the description of Berry and Pryce (2014). As feed intake had to be estimated, residual feed intake could not be considered; therefore, only ratio-based efficiency traits were investigated. Efficiency at each test-day was defined as ratio of milk output to metabolic $\mathrm{BW}\left(\mathrm{ECM} / \mathrm{BW}^{0.75}\right.$, BW efficiency), ratio of milk output to DMI (ECM/DMI, feed efficiency), and ratio of milk energy output to total energy intake (LE/ INEL, where LE = energy in milk; energy efficiency).

$\boldsymbol{B C S}$. Body condition score was recorded at each test-day on a scale from 1 (severe underconditioning) to 5 (severe overconditioning) in increments of 0.25 (Edmonson et al., 1989).

Lameness. Lameness was recorded at each test-day using the scoring system by Sprecher et al. (1997), where $1=$ normal, $2=$ mildly lame, $3=$ moderately lame, $4=$ lame, and $5=$ severely lame.

\section{Data Edits}

Analyses were carried out for Fleckvieh, Brown Swiss, and Holstein cows with a maximum foreign gene proportion of $25 \%$ from all parities; only data from 5 to 365 DIM were considered. Dry cows were excluded 
Table 1. Summary statistics for analyzed traits [ECM, BW, DMI, energy intake (INEL), body weight efficiency $\left(\mathrm{ECM} / \mathrm{BW}^{0.75}\right)$, feed efficiency (ECM/DMI), energy efficiency (LE/INEL, LE = energy in milk), BCS, and lameness] in Fleckvieh, Brown Swiss, and Holstein

\begin{tabular}{|c|c|c|c|c|}
\hline Item & $\mathrm{N}$ & Mean & SD & $\mathrm{CV}, \%$ \\
\hline \multicolumn{5}{|l|}{ Fleckvieh } \\
\hline ECM, kg/d & 20,945 & 27.4 & 8.1 & 30 \\
\hline $\mathrm{BW}, \mathrm{kg}$ & 20,945 & 731 & 85 & 12 \\
\hline DMI, $\mathrm{kg} / \mathrm{d}$ & 20,945 & 19.4 & 2.6 & 14 \\
\hline INEL, MJ of $\mathrm{NE}_{\mathrm{L}} / \mathrm{d}$ & 20,945 & 127.6 & 21.5 & 17 \\
\hline $\mathrm{ECM} / \mathrm{BW}^{0.75}$ & 20,945 & 0.196 & 0.057 & 29 \\
\hline ECM/DMI & 20,945 & 1.39 & 0.29 & 21 \\
\hline LE/INEL & 20,945 & 0.680 & 0.139 & 20 \\
\hline BCS & 20,882 & 3.29 & 0.55 & 17 \\
\hline Lameness & 20,813 & 1.29 & 0.66 & 51 \\
\hline \multicolumn{5}{|l|}{ Brown Swiss } \\
\hline ECM, kg/d & 9,749 & 26.6 & 8.2 & 31 \\
\hline $\mathrm{BW}, \mathrm{kg}$ & 9,749 & 652 & 76 & 12 \\
\hline DMI, $\mathrm{kg} / \mathrm{d}$ & 9,749 & 18.9 & 2.6 & 14 \\
\hline INEL, MJ of $\mathrm{NE}_{\mathrm{L}} / \mathrm{d}$ & 9,749 & 124.2 & 21.3 & 17 \\
\hline $\mathrm{ECM} / \mathrm{BW}^{0.75}$ & 9,749 & 0.207 & 0.062 & 30 \\
\hline ECM/DMI & 9,749 & 1.39 & 0.30 & 22 \\
\hline LE/INEL & 9,749 & 0.679 & 0.145 & 21 \\
\hline $\mathrm{BCS}$ & 9,459 & 3.06 & 0.51 & 17 \\
\hline Lameness & 9,739 & 1.24 & 0.62 & 50 \\
\hline \multicolumn{5}{|l|}{ Holstein } \\
\hline ECM, kg/d & 7,037 & 31.8 & 9.3 & 29 \\
\hline $\mathrm{BW}, \mathrm{kg}$ & 7,037 & 662 & 77 & 12 \\
\hline DMI, kg/d & 7,037 & 20.9 & 3.1 & 15 \\
\hline INEL, MJ of $\mathrm{NE}_{\mathrm{L}} / \mathrm{d}$ & 7,037 & 140.3 & 24.3 & 17 \\
\hline $\mathrm{ECM} / \mathrm{BW}^{0.75}$ & 7,037 & 0.245 & 0.070 & 29 \\
\hline ECM/DMI & 7,037 & 1.50 & 0.31 & 21 \\
\hline LE/INEL & 7,037 & 0.717 & 0.146 & 20 \\
\hline BCS & 6,929 & 2.85 & 0.64 & 22 \\
\hline Lameness & 6,973 & 1.44 & 0.75 & 52 \\
\hline
\end{tabular}

from the analyses. After edits, in total, 37,525 records from 5,942 cows (3,312 Fleckvieh, 1,478 Brown Swiss, and 1,152 Holstein) were used for analyses. A summary of statistics of the analyzed data sets is given in Table 1. Animal pedigree files were generated for each breed by tracing back as many generations as possible for cows with records. The number of animals within each pedigree was 34,842, 15,598, and 15,525 for Fleckvieh, Brown Swiss, and Holstein, respectively.

\section{Models}

Data were analyzed with univariate and bivariate linear animal models using the average information (AI)-REML procedure in the DMU package (Madsen and Jensen, 2008). Breeding values were obtained from univariate analyses. The following model was applied to all traits:

$$
\mathbf{y}=\mathbf{X} \boldsymbol{\beta}+\mathbf{Z}_{\mathrm{h}} \mathbf{h}+\mathbf{Z}_{\mathrm{pe}} \mathbf{p e}+\mathbf{Z}_{\mathrm{a}} \mathbf{a}+\mathbf{e}
$$

where $\mathbf{y}$ is a vector of observations; $\boldsymbol{\beta}$ is a vector of systematic effects, including fixed effects of herd, yearseason of calving, parity-age at calving, parity-lactation stage, parity-pregnancy stage, and classifier (for BCS and lameness); $\mathbf{h}$ is a vector of random herd-test-day effects; pe is a vector of random permanent environmental effects; $\mathbf{a}$ is a vector of random animal additive genetic effects; e is a vector of random residuals; and $\mathbf{X}, \mathbf{Z}_{\mathrm{h}}, \mathbf{Z}_{\mathrm{pe}}$, and $\mathbf{Z}_{\mathrm{a}}$ are the corresponding incidence matrices.

Seasons were formed by combining 3 consecutive months (January-March, April-June, July-September, and October-December). Parity had 3 classes: 1, 2, and $3+$. Calving age classes were formed for each of the first 2 parities. Age at first calving had 6 classes, in which $<26$ and $>34$ mo were the first and last classes, respectively, and other classes were 2-mo classes. Age at second calving was grouped into 6 classes, in which $<39$ mo was the first class, $>47$ mo was the last class, and other classes were 2-mo classes. For older cows, age-parity classes were parity 3 . Lactation stage was defined in classes, with each month after calving representing a single class $(1=5-30$ DIM, $2=31-60$ DIM, $\ldots, 11=301-330,12=331-365$ DIM). Pregnancy stage was defined in 8 classes as $1=$ not pregnant, $2=$ $1-90 \mathrm{~d}, 3=91-120 \mathrm{~d}, 4=121-150,5=151-180 \mathrm{~d}, 6=$ $181-210 \mathrm{~d}, 7=211-240 \mathrm{~d}, 8=\geq 241 \mathrm{~d}$. 

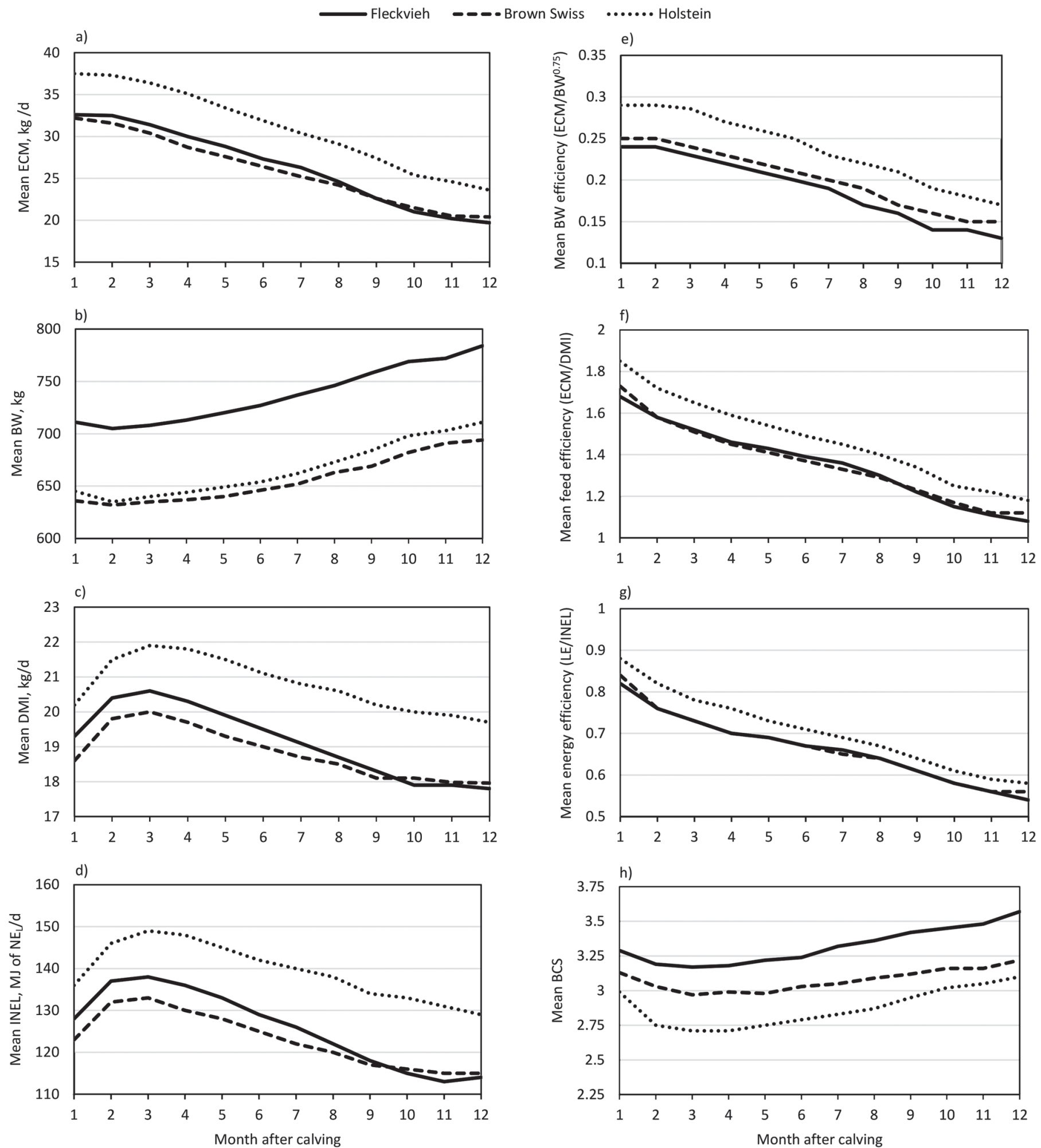

Figure 1. Mean ECM, BW, DMI, energy intake (INEL), BW efficiency (ECM/BW ${ }^{0.75}$ ), feed efficiency (ECM/DMI), energy efficiency (LE/ INEL, LE = energy in milk), and BCS during lactation of Fleckvieh, Brown Swiss and Holstein cows. 
Table 2. Proportions (\%) of different lameness score records for Fleckvieh, Brown Swiss, and Holstein

\begin{tabular}{lcccccc}
\hline Breed & $\begin{array}{c}\text { No. of } \\
\text { records }\end{array}$ & Normal & $\begin{array}{c}\text { Mildly } \\
\text { lame }\end{array}$ & $\begin{array}{c}\text { Moderately } \\
\text { lame }\end{array}$ & Lame & $\begin{array}{c}\text { Severely } \\
\text { lame }\end{array}$ \\
\hline Fleckvieh & 20,813 & 79.3 & 14.3 & 4.2 & 1.9 & 0.3 \\
Brown Swiss & 9,739 & 83.0 & 11.4 & 3.9 & 1.4 & 0.3 \\
Holstein & 6,973 & 68.4 & 22.2 & 6.9 & 2.1 & 0.4 \\
\hline
\end{tabular}

Random effects were assumed normally distributed, with means equal to zero, and covariance structure in the bivariate analyses was equal to

$$
\operatorname{Var}\left[\begin{array}{l}
h \\
a \\
p e \\
e
\end{array}\right]=\left[\begin{array}{cccc}
\mathbf{H}_{0} \otimes \mathbf{I} & 0 & 0 & 0 \\
& \mathbf{G}_{0} \otimes \mathbf{A} & 0 & 0 \\
& & \mathbf{P E}_{0} \otimes \mathbf{I} & 0 \\
\text { symm. } & & & \mathbf{R}_{0} \otimes \mathbf{I}
\end{array}\right],
$$

where $\mathbf{H}_{0}$ is the $($ co) variance $(2 \times 2)$ matrix for herdtest-day effects; $\mathbf{G}_{0}$ is the genetic (co)variance $(2 \times$ 2) matrix; $\mathbf{P E}_{0}$ is the permanent environmental (co) variance $(2 \times 2)$ matrix, $\mathbf{R}_{0}$ is the residual (co)variance $(2 \times 2)$ matrix, $\mathbf{I}$ and $\mathbf{A}$ are identity and additive relationship matrices, respectively, and $\otimes$ is the Kronecker product.

\section{RESULTS AND DISCUSSION}

\section{Phenotypic Description}

Figure 1 shows the mean values for ECM, BW, DMI, INEL, ECM/BW ${ }^{0.75}$, ECM/DMI, LE/INEL, and BCS during the lactation for the 3 Austrian breeds. Holstein cows had the highest milk yield, DMI, INEL, and efficiency and the lowest BCS during lactation. Body weight and BCS were highest in Fleckvieh, and Brown Swiss had the lowest frequency of lame cows (Table 2). Figure 2 shows the percentage of normal and lame cows at each stage of lactation. The percentage of lame cows was consistent over the lactation.

\section{Genetic Parameters}

Heritabilities and repeatabilities for the analyzed traits for Fleckvieh, Brown Swiss, and Holstein are shown in Table 3. For Fleckvieh, the heritability estimates of the efficiency (related) traits ranged from 0.11 for LE/INEL to 0.44 for BW. Heritabilities for BCS and lameness were 0.19 and 0.07 , respectively. High repeatabilities in the range of 0.30 for LE/INEL to 0.83 for BW were obtained. For Brown Swiss and Holstein, heritabilities were generally lower, except for BCS. However, as fewer records were available for these breeds, standard errors were slightly higher, and therefore heritabilities were estimated with greater uncertainty. Repeatabilities were in the same range as for Fleckvieh. The low heritability estimates for ECM of 0.12, 0.08, and 0.09 for Fleckvieh, Brown Swiss, and
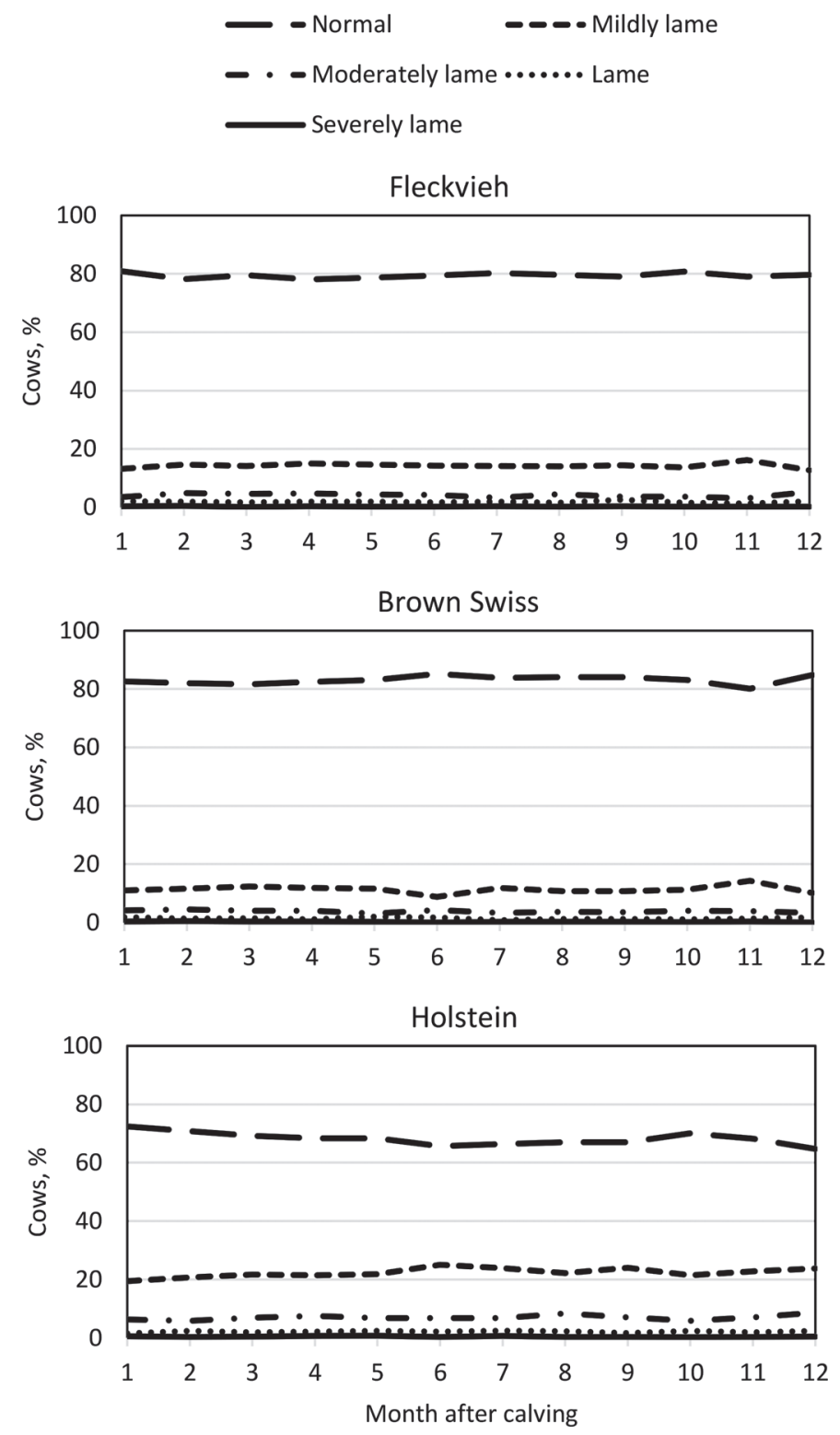

Figure 2. Percentage (\%) of Fleckvieh, Brown Swiss, and Holstein cows recorded as being not lame (normal), mildly lame, moderately lame, lame, and severely lame during lactation. 
Table 3. Heritabilities ( $\mathrm{h}^{2}, \mathrm{SE}$ in parentheses) and repeatabilities (R) for ECM, BW, DMI, energy intake (INEL), BW efficiency (ECM/BW $\left.{ }^{0.75}\right)$, feed efficiency (ECM/DMI), energy efficiency (LE/INEL, LE = energy in milk), BCS, and lameness

\begin{tabular}{|c|c|c|c|c|c|c|}
\hline Item & \multicolumn{2}{|c|}{ Fleckvieh } & \multicolumn{2}{|c|}{ Brown Swiss } & \multicolumn{2}{|c|}{ Holstein } \\
\hline BW & $0.44(0.05)$ & 0.83 & $0.38(0.07)$ & 0.79 & $0.31(0.07)$ & 0.80 \\
\hline DMI & $0.18(0.03)$ & 0.45 & $0.10(0.03)$ & 0.48 & $0.08(0.04)$ & 0.51 \\
\hline INEL & $0.13(0.02)$ & 0.36 & $0.07(0.03)$ & 0.40 & $0.07(0.03)$ & 0.42 \\
\hline $\mathrm{ECM} / \mathrm{BW}^{0.75}$ & $0.17(0.03)$ & 0.44 & $0.12(0.03)$ & 0.43 & $0.14(0.05)$ & 0.51 \\
\hline BCS & $0.19(0.03)$ & 0.56 & $0.23(0.05)$ & 0.60 & $0.28(0.06)$ & 0.65 \\
\hline Lameness & $0.07(0.02)$ & 0.34 & $0.04(0.02)$ & 0.35 & $0.05(0.03)$ & 0.34 \\
\hline
\end{tabular}

Holstein, respectively, could be because larger and better farms with regard to milk production participated in the project, which might have decreased genetic variability. Manzanilla-Pech et al. (2014) estimated a similar heritability for BW (0.38) for first-parity Dutch Holstein cows but significantly higher estimates for fatand protein-corrected milk (0.46) and DMI (0.46) over the whole lactation based on a multivariate random regression model. Li et al. (2016) reported heritability estimates for DMI in the range of 0.20 to 0.40 in Holsteins, 0.25 to 0.41 in Nordic Red, and 0.17 to 0.42 in Jerseys within the first 24 wk of lactation. Hurley et al. (2017) investigated several ratio-based efficiency traits and found heritabilities in the range of 0.06 to 0.33 . Heritabilities for BCS were in the range of literature values with estimates ranging from 0.15 to 0.64 (Dal Zotto et al., 2007; Vallimont et al., 2010; Kougioumtzis et al., 2014). Weber et al. (2013) defined lameness as a binary trait $(0=$ lameness score of 1 or $2,1=$ lameness score of $\geq 3$ ) and found a heritability of 0.08 based on a linear model.

\section{Genetic Correlations}

Genetic correlations between traits are given in Tables 4, 5, and 6 for Fleckvieh, Brown Swiss, and Holstein, respectively.

Efficiency (Related) Traits. For the 3 Austrian breeds, weak negative genetic correlations were obtained between ECM and BW. Genetic correlations close to zero between BW at different stages of lactation and total lactation milk production were also reported by Berry et al. (2003). In a more recent study, ManzanillaPech et al. (2014) reported slightly negative genetic correlations between fat- and protein-corrected milk and BW in early lactation and at the end of lactation.

Genetic correlations near unity were found between DMI and INEL. Also, ECM/BW ${ }^{0.75}$, ECM/DMI, and LE/INEL were strongly correlated, with genetic correlation estimates $>0.92$. Moderate genetic correlations were found between DMI and ECM as well as BW in the range of 0.35 to 0.66 . Manzanilla-Pech et al. (2014) obtained similar genetic correlations over the whole lactation based on experimental research data, with estimates of 0.86 between DMI and fat- and proteincorrected milk yield and 0.45 between DMI and BW.

The 3 efficiency traits, ECM/BW ${ }^{0.75}$, ECM/DMI, and LE/INEL, were strongly positively correlated with milk yield, negatively correlated with BW, and positively correlated with DMI and INEL, which confirmed the results obtained by Vallimont et al. (2011). Selection for higher milk yield and lower BW will increase feed efficiency.

$\boldsymbol{B C S}$. Negative genetic correlations were found for BCS with ECM, ECM/BW ${ }^{0.75}$, ECM/DMI, and LE/ INEL in the 3 Austrian breeds, which highlights that more-efficient cows have a lower BCS during lactation. In a preliminary study in Austrian Fleckvieh, a low BCS during lactation was associated with a longer calving interval and higher disease rates of metabolic diseases, fertility diseases, mastitis, and claw diseases (Köck et al., 2017). Numerous previous studies showed the link between low BCS during lactation and increased fertility and health problems in Brown Swiss (Dal Zotto et al., 2007) and Holstein (Dechow et al., 2004; Koeck et al., 2012) cows. High negative genetic correlations between BCS and efficiency traits in the range of -0.64 to -0.70 were also reported by Vallimont et al. (2011). Those authors expressed concern that failure to account for body tissue mobilization would identify as efficient cows that lose more BCS at the beginning of the lactation. Such selection would not improve efficiency because cow health and fertility would be compromised. Therefore, the additional information of BCS, fertility, and health is needed when selecting for higher efficiency.

Body condition score was moderately correlated with BW, with estimates of $0.46,0.56$, and 0.51 for Fleckvieh, Brown Swiss, and Holstein, respectively, which is in agreement with previous studies. Vallimont et al. 
GENETIC PARAMETERS FOR EFFICIENCY TRAITS
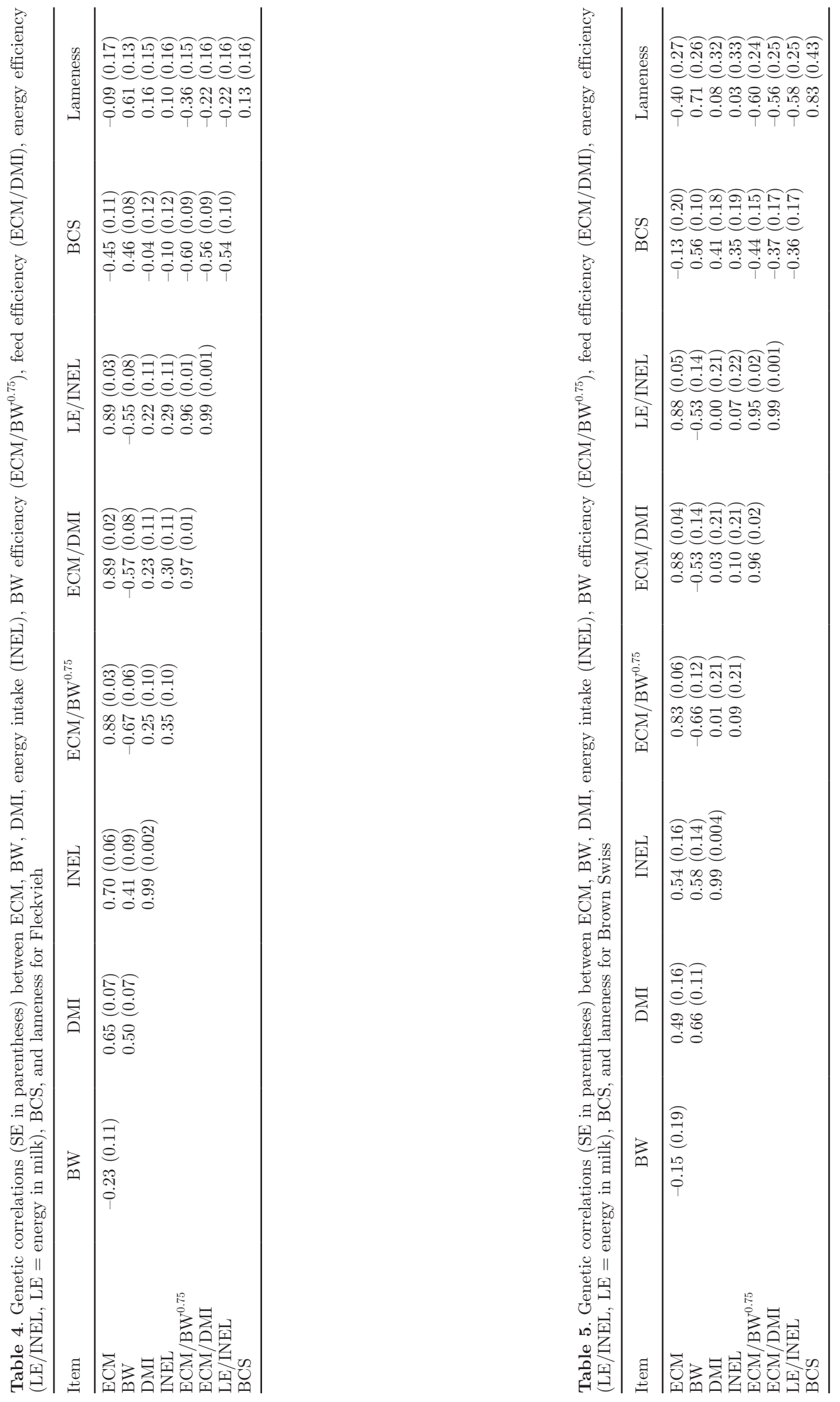


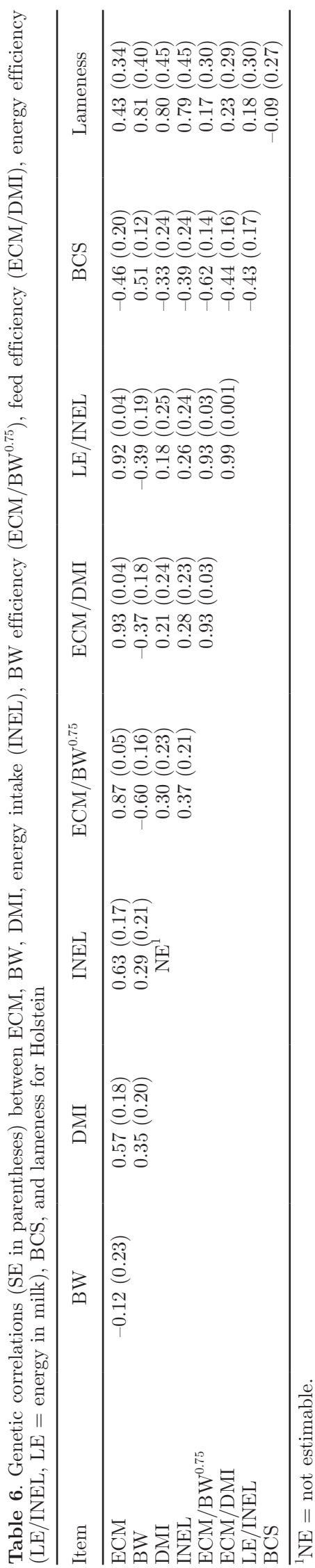

(2010) reported a genetic correlation of 0.50 between BCS and BW in Holstein cows.

Lameness. Genetic correlations between lameness and other traits revealed moderate positive genetic correlations between $\mathrm{BW}$ and lameness, indicating that heavier animals are more prone to lameness. Interestingly, genetic correlations between lameness and the efficiency traits ECM/BW ${ }^{0.75}$, ECM/DMI, and LE/ INEL were favorable in Fleckvieh and Brown Swiss, suggesting that more-efficient cows have fewer lameness problems. The genetic correlation estimates between BCS and lameness were not significantly different from zero. Genetic correlation estimates involving lameness were associated with large standard errors. Therefore, EBV were estimated for ECM, BW, DMI, LE/INEL, and BCS, and the distribution of the lameness scores was compared from the top and bottom $10 \%$ cows ranked by their respective EBV (Table 7). A low EBV for BW was associated with fewer mildly lame cases, especially in Fleckvieh. In contrast, Brown Swiss and Holstein cows with a low EBV for BW had an increased incidence of moderately lame and lame cases, which was not visible in the genetic correlation estimates. The reason for this finding seems to be the positive correlation between BW and BCS. By selecting for a lower BW, BCS is also decreasing, which is especially undesirable in breeds with a lower BCS. Frigo et al. (2010) found that greater BW and less BW change in Holsteins during the first 120 DIM were associated with lower incidences of ketosis, metabolic diseases, infectious diseases, and other diseases.

A high EBV for DMI was associated with a lower incidence of lame cows. Norring et al. (2014) observed that cows with more severe lameness spent less time feeding per day. Worsening of gait was associated with lower silage intake and less time spent feeding, even before severe lameness was scored.

Confirming the genetic correlation estimates, moreefficient animals had slightly fewer lameness problems in all 3 breeds. Possible reasons could be the lower BW (especially in Fleckvieh) and higher DMI of the moreefficient cows. A low EBV for BCS was associated with a higher frequency of lameness. Also, Kougioumtzis et al. (2014) found statistically significant genetic correlations for first-lactation weekly locomotion score and $\mathrm{BCS}$, ranging from -0.31 to -0.65 , suggesting that cows genetically predisposed for high BCS have fewer locomotion problems.

\section{Final Remarks}

$\boldsymbol{B} \boldsymbol{W}$. Recent studies from Austria have shown that the highest efficiency of a population is achieved with medium BW (Gruber and Ledinek, 2017). In the cur- 
Table 7. Distribution of lameness scores from the top and bottom 10\% cows ranked by their EBV for ECM, BW, DMI, energy efficiency (LE/ INEL, LE = energy in milk, INEL = energy intake) and BCS for Fleckvieh, Brown Swiss, and Holstein

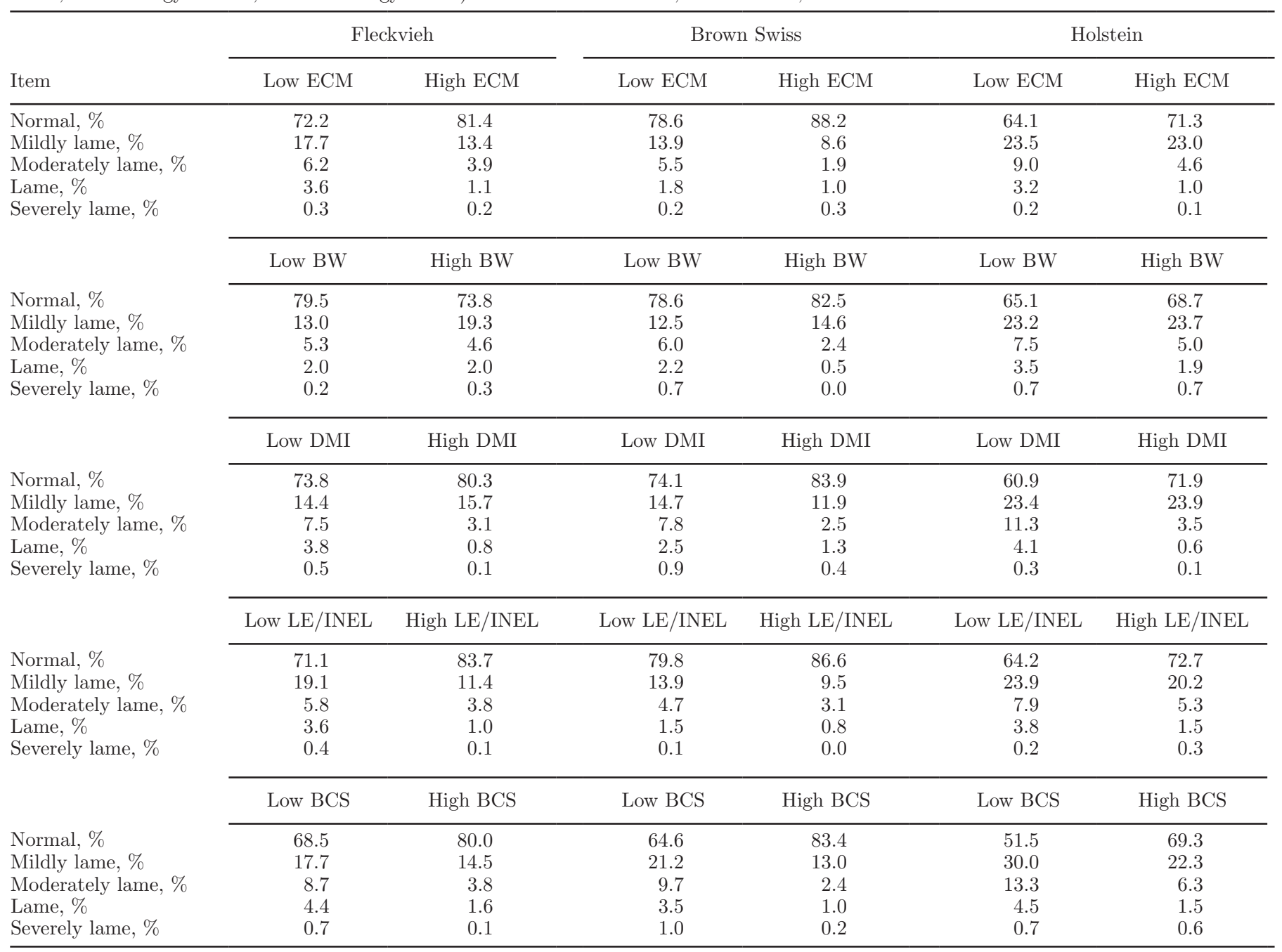

rent breeding program, BW is not included. However, if BW were included in future dairy cattle breeding programs, the positive correlation between BW and BCS has to be considered. Figure 3 shows the mean BCS from the top and bottom $10 \%$ cows ranked by their EBV for BW for Fleckvieh, Brown Swiss, and Holstein. As illustrated, selection for a lower BW results in an undesirable decrease in BCS. For this reason, BCS is required as additional information when selecting for a lower BW; otherwise, no distinction can be made between large animals with low BCS and smaller animals with normal BCS.

$\boldsymbol{D} \boldsymbol{M I}$. Dry matter intake is not recorded in commercial herds on a large scale. Therefore, in most published studies, the number of DMI records is small and estimates of genetic parameters have large standard errors. In the study of Manzanilla-Pech et al. (2014), data from historical nutritional experiments from Holstein cows calving between 1990 and 2011 in the Netherlands was combined and a large data set was created. This resulted in a data set consisting of 30,483 records for DMI on 1,297 first-parity cows. In the present study, a different approach was chosen. To obtain information on feed intake on a relatively large number of cows, DMI was estimated according to the model of Gruber et al. (2004). Compared with recorded DMI data from experimental herds, heritabilities for DMI were generally lower; however, genetic correlation estimates between DMI and other traits were similar, which highlights the usefulness of this data.

Overall Efficiency. Efficiency is understood as a combination of already existing traits of milk, beef, and functional traits and traits aiming at feed efficiency and health. In the current study, efficiency was defined as ECM/BW ${ }^{0.75}$, ECM/DMI, and LE/INEL. For the whole assessment of efficiency, longevity, fertility, and 


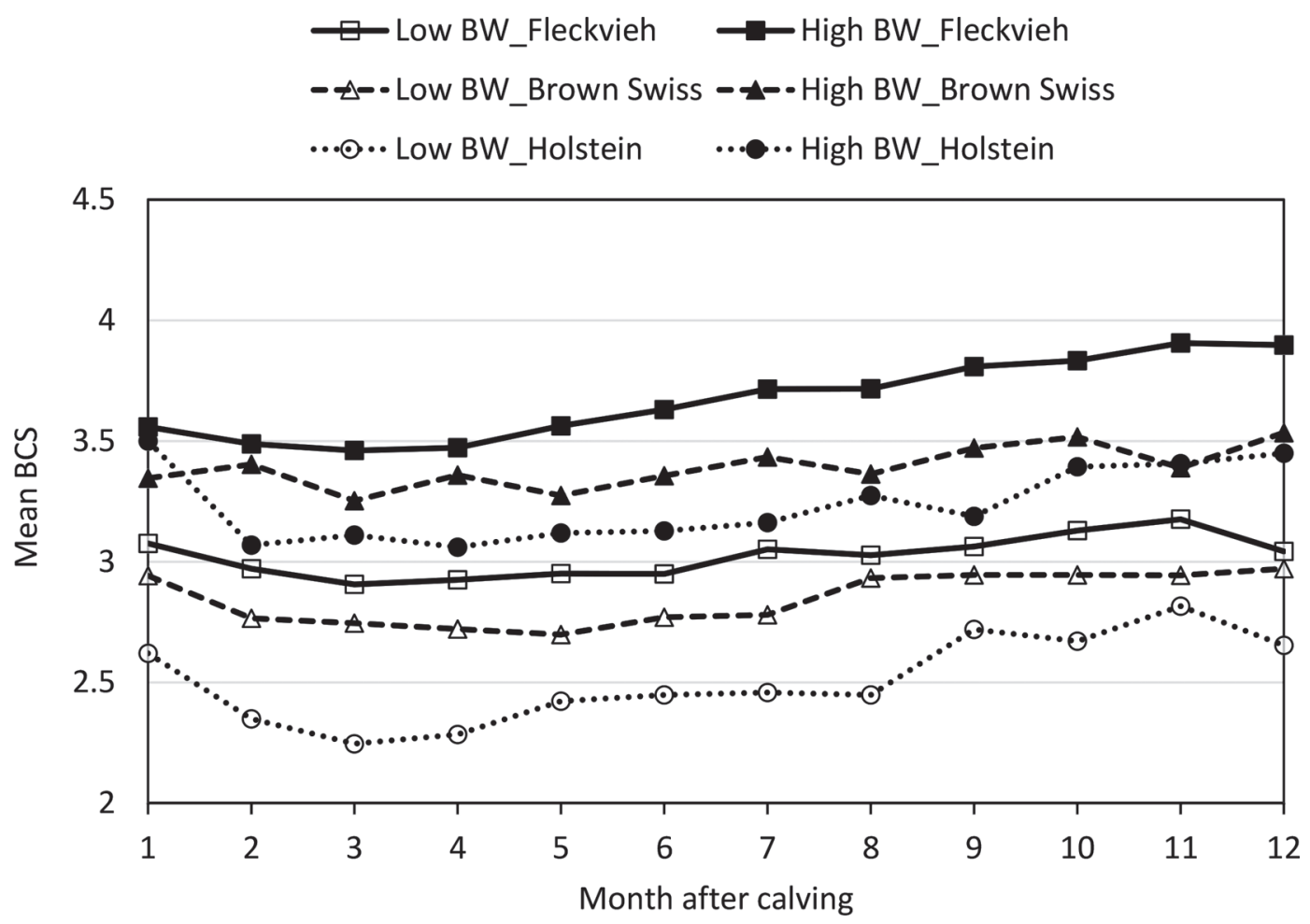

Figure 3. Mean BCS from the top and bottom $10 \%$ of cows ranked by their EBV for BW for Fleckvieh, Brown Swiss, and Holstein.

health are also important. In a preliminary study in Austrian Fleckvieh, cows with higher efficiency had a longer calving interval and higher frequencies of fertility disorders (cystic ovaries and silent heat). Higher efficiency was associated with a slightly lower incidence of claw diseases, which was confirmed in the present study with a lower incidence of lameness. More-efficient animals had the lowest culling rates. Overall, cows with moderate efficiency combine high milk performance with good fertility and health (Köck et al., 2017). Vallimont et al. (2013) reported that Holstein cows with higher feed efficiency had greater days open but remained longer in the herd.

\section{CONCLUSIONS}

The results from the study showed sufficient genetic variation of the efficiency traits based on field data. As expected, more-efficient animals have a higher milk yield. Because the additional energy requirement cannot be fully covered by the increased feed intake, moreefficient animals mobilize more body reserves. Partly due to the lower BW (especially in Fleckvieh) and higher DMI, more-efficient animals have slightly fewer lameness problems. When selecting for lower BW, it is important to note that BCS is required as additional information; otherwise, no distinction can be made be- tween large animals with low BCS and smaller animals with normal BCS.

\section{ACKNOWLEDGMENTS}

The study was supported by the project "Efficient Cow" funded by the Austrian Federal Ministry of Agriculture, Forestry, Environment and Water Management (Vienna); the Federations of Austrian Fleckvieh (Zwettl), Brown-Swiss (Innsbruck), Holstein (Leoben), the Federation of Austrian Cattle Breeders (Vienna) and the COMET K-Project "ADDA-Advancement of Dairying in Austria" (Vienna). This project was supported by BMVIT (Austrian Ministry for Transport, Innovation and Technology), BMWFW (Federal Ministry of Science, Research and Economy), the province of Lower Austria, and the city of Vienna in the framework of COMET-Competence Centers for Excellent Technologies. The COMET program is handled by the FFG (Austrian Research Promotion Agency).

\section{REFERENCES}

Berry, D. P., F. Buckley, P. Dillon, R. D. Evans, M. Rath, and R. F. Veerkamp. 2003. Genetic relationships among body condition score, body weight, milk yield and fertility in dairy cows. J. Dairy Sci. 86:2193-2204. 
Berry, D. P., and J. J. Crowley. 2013. Cell Biology Symposium: Genetics of feed efficiency in dairy and beef cattle. J. Anim. Sci. 91:1594-1613.

Berry, D. P., and J. E. Pryce. 2014. Feed efficiency in growing and mature animals. In Proc. 10th Word Congress of Genetics Applied to Livestock Production. Vancouver 2014. Accessed Oct. 25, 2017. https://www.asas.org/docs/default-source/wcgalp-proceedings -oral/109_paper_10258_manuscript_1631_0.pdf?sfvrsn=2.

Connor, E. E. 2015. Invited review: Improving feed efficiency in dairy production: challenges and possibilities. Animal 9:395-408.

Dal Zotto, R., M. De Marchi, C. Dalvit, M. Cassandro, L. Gallo, P. Carnier, and G. Bittante. 2007. Heritabilities and genetic correlations of body condition score and calving interval with yield, somatic cell score, and linear type traits in Brown Swiss cattle. J. Dairy Sci. 90:5737-5743.

Dechow, C. D., G. W. Rogers, U. Sander-Nielsen, L. Kiel, T. J. Lawlor, J. S. Clay, A. E. Freeman, G. Abdel-Azim, A. Kuck, and S. Schnell. 2004. Correlations among body conditions scores from various sources, dairy form, and cow health from the United States and Denmark. J. Dairy Sci. 87:3526-3533.

Edmonson, A. J., I. J. Lean, L. D. Weaver, T. Farver, and G. Webster. 1989. A body condition scoring chart for Holstein dairy cows. J. Dairy Sci. 72:68-78.

Frigo, E., C. D. Dechow, O. Pedroon, and B. G. Cassell. 2010. The genetic relationship of body weight and early-lactation health disorders in two experimental herds. J. Dairy Sci. 93:1184-1192.

GfE (Gesellschaft für Ernährungsphysiologie - Ausschuss für Bedarfsnormen). 2001. Energie- und Nährstoffbedarf landwirtschaftlicher Nutztiere, Nr. 8: Empfehlungen zur Energie- und Nährstoffversorgung der Milchkühe und Aufzuchtrinder. DLG-Verlag, Frankfurt am Main, Germany.

Gruber, L., and M. Ledinek. 2017. Efficiency of milk production depending on genotype and live weight. Viehwirtschaftliche Fachtagung 2017:23-39.

Gruber, L., F. J. Schwarz, D. Erdin, B. Fischer, H. Spiekers, H Steingaß, U. Meyer, A. Chassot, T. Jilg, A. Obermaier, and T. Guggenberger. 2004. Vorhersage der Futteraufnahme von Milchkühen - Datenbasis von 10 Forschungs- und Universitätsinstituten Deutschlands, Österreichs und der Schweiz. In Qualitätssicherung in landwirtschaftlichen Produktionssystemen. 116. VDLUFAKongress, Rostock 2004 (pp. 484-504). VDLUFA-Verlag, Speyer, Germany.

Huhtanen, P., M. Rinne, P. Mäntysaari, and J. Nousiainen. 2011. Integration of the effects of animal and dietary factors on total dry matter intake of dairy cows fed silage- based diets. Animal 5:691-702.

Hurley, A. M., N. López-Villalobos, S. McParland, E. Lewis, E. Kennedy, M. O'Donovan, J. L. Burke, and D. P. Berry. 2017. Genetics of alternative definitions of feed efficiency in grazing lactation dairy cows. J. Dairy Sci. 100:5501-5514.

Jensen, L. M., N. I. Nielsen, E. Nadeau, B. Markussen, and P. Nørgaard. 2015. Evaluation of five models predicting feed intake by dairy cows fed total mixed rations. Livest. Sci. 176:91-103.

Köck, A., M. Ledinek, L. Gruber, F. Steininger, B. Fürst-Waltl, and C. Egger-Danner. 2017. Zucht auf Effizienzmerkmale und deren Zusammenhang mit Gesundheit. Pages $52-58$ in ZAR Seminar 2017. Accessed Aug. 23, 2017. https://www.zar.at/Downloads/ ZAR-Seminar.html.

Koeck, A., F. Miglior, D. F. Kelton, and F. S. Schenkel. 2012. Short communication: Genetic association of body condition score with disease resistance in first lactation Canadian Holsteins. Can. J. Anim. Sci. 92:285-289.

Kougioumtzis, A., G. E. Valergakis, G. Oikonomou, G. Arsenos, and G. Banos. 2014. Profile and genetic parameters of dairy cattle locomotion score and lameness across lactation. Animal 8:20-27.

Ledinek, M., L. Gruber, F. Steininger, B. Fuerst-Waltl, K. Zottl, M. Royer, K. Krimberger, M. Mayerhofer, and C. Egger-Danner.
2017. Futter- und Nährstoffeffizienz - was steckt dahinter? ZAR Seminar 2017: 10-17. Accessed Aug. 23, 2017. https://www.zar .at/Downloads/ZAR-Seminar.html.

Ledinek, M., L. Gruber, F. Steininger, B. Fürst-Waltl, K. Zottl, M. Royer, K. Krimberger, M. Mayerhofer, and C. Egger-Danner. 2016. Efficient Cow - Estimation of feed intake for efficiency traits using on-farm recorded data. 24th International Symposium Animal Science Days, Ptuj, Slovenia. Acta Agric. Slov. Supplement 5:71-75.

Li, B., W. F. Fikse, J. Lassen, M. H. Lidauer, P. Løvendahl, P. Mäntysaari, and B. Berglund. 2016. Genetic parameters for dry matter intake in primiparous Holstein, Nordic Red, and Jersey cows in the first halt of lactation. J. Dairy Sci. 99:7232-7239.

Madsen, P., and J. Jensen. 2008. A User's Guide to DMU. A package for analyzing multivariate mixed models. Version 6 , release 4.7 Danish Institute of Agricultural Sciences, Tjele, Denmark.

Manzanilla-Pech, C. I., R. F. Veerkamp, M. P. L. Calus, R. Zom, A. van Knegsel, J. E. Pryce, and Y. De Haas. 2014. Genetic parameters across lactation for feed intake, fat- and protein-corrected milk, and liveweight in first-parity Holstein cattle. J. Dairy Sci. 97:5851-5862.

Norring, M., J. Häggman, H. Simojoki, P. Tamminen, C. Winckler, and M. Pastell. 2014. Short communication: Lameness impairs feeding behavior of dairy cows. J. Dairy Sci. 97:4317-4321.

NRC. 2001. Nutrient Requirements of Dairy Cattle. 7th ed. National Academies Press, Washington, DC

Sprecher, D. J., D. E. Hostetler, and J. B. Kaneene. 1997. A lameness scoring system that uses posture and gait to predict dairy cattle reproductive performance. Theriogenology 47:1179-1187.

Steininger, F., C. Fuerst, B. Fuerst-Waltl, L. Gruber, M. Mayerhofer, M. Ledinek, R. Weissensteiner, W. Zollitsch, K. Zottl, and C. Egger-Danner. 2015. Efficient cow-Strategies for on-farm collecting of phenotypes for efficiency traits. ICAR Technical Workshop, Krakow 2015. ICAR Technical Series 19:167-173.

Vallimont, J. E., C. D. Dechow, J. M. Daubert, M. W. Dekleva, J. W. Blum, C. M. Barlieb, W. Liu, G. A. Varga, A. J. Heinrichs and C. R. Baumrucker. 2010. Genetic parameters for feed intake, production, body weight, body condition score, and selected type traits of Holstein cows in commercial tie- stall barns. J. Dairy Sci. 93:4892-4901.

Vallimont, J. E., C. D. Dechow, J. M. Daubert, M. W. Dekleva, J. W. Blum, C. M. Barlieb, W. Liu, G. A. Varga, A. J. Heinrichs, and C. R. Baumrucker. 2011. Short communication: Heritability of gross feed efficiency and associations with yield, intake, residual intake, body weight, and body condition score in 11 commercial Pennsylvania tie stalls. J. Dairy Sci. 94:2108-2113.

Vallimont, J. E., C. D. Dechow, J. M. Daubert, M. W. Dekleva, J. W. Blum, W. Liu, G. A. Varga, A. J. Heinrichs, and C. R. Baumrucker. 2013. Short communication: Feed utilization and its associations with fertility and productive life in 11 commercial Pennsylvania tie-stall herds. J. Dairy Sci. 96:1251-1254.

VandeHaar, M. J. 2014. Feeding and breeding for a more efficient cow. Dairy Technol. 26:17-30.

Volden, H., N. I. Nielsen, M. Åkerlind, M. Larsen, Ø. Havrevoll, and A. J. Rygh. 2011. Prediction of voluntary feed intake. Pages 113-126 in The Nordic Feed Evaluation System. H. Volden, ed. EAAP Publication No. 130. Wageningen Academic Publishers, Wageningen, the Netherlands.

Weber, A., E. Stamer, W. Junge, and G. Thaller. 2013. Genetic parameters for lameness and claw and leg diseases in dairy cattle. J. Dairy Sci. 96:3310-3318.

Zom, R. L. G., G. Andre, and A. M. Van Vuuren. 2012a. Development of a model for the prediction of feed intake by dairy cows: 1 . Prediction of feed intake. Livest. Sci. 143:43-57.

Zom, R. L. G., G. Andre, and A. M. Van Vuuren. 2012b. Development of a model for the prediction of feed intake by dairy cows: 2 . Evaluation of prediction accuracy. Livest. Sci. 143:58-69. 